International Journal of Civil Engineering and Technology (IJCIET)

Volume 9, Issue 9, September 2018, pp. 1309-1319, Article ID: IJCIET_09_09_126

Available online at http://www.iaeme.com/ijciet/issues.asp?JType=IJCIET\&VType=9\&IType=9

ISSN Print: 0976-6308 and ISSN Online: 0976-6316

OIAEME Publication

Scopus Indexed

\title{
A REVIEW OF ICT IN GOVERNMENT BUREAUCRACY: PSYCHOLOGICAL AND TECHNOLOGY SKILL PERSPECTIVES
}

\author{
Kaiman Turnip \\ Faculty of Psychology, Universitas Medan Area, Medan, Indonesia \\ Andre Hasudungan Lubis \\ Faculty of Engineering, Universitas Medan Area, Medan, Indonesia \\ Sutrisno \\ Faculty of Engineering, Universitas Medan Area, Medan, Indonesia \\ Maksyum Syahri Lubis \\ Faculty of Social and Politic, Universitas Medan Area, Medan, Indonesia
}

\begin{abstract}
ICT/E-Government has become the crucial issue regarding the developing countries. The technology facilitates to accelerate efforts to improve the performance of the government bureaucracy which so far is considered unable to provide excellent service to society. This paper addresses the issue by demonstrating a recommendation of study to identify the relationship between psychological and technology skill perspectives towards the implementation of ICT usage or E-Government. Attitudes, ease of use and perceived usefulness among government bureaucratic are the strong factor to use the technology. Both TAM and UTAUT are considered to be the underpinning model. As a result, the article expected that the following study would discover the similar results towards the previous studies.
\end{abstract}

Key words: ICT, Government Bureaucracy, Psychological, Technology Skill

Cite this Article: Kaiman Turnip, Andre Hasudungan Lubis, Sutrisno, Maksyum Syahri Lubis, A Review of ICT in Government Bureaucracy: Psychological and Technology Skill Perspectives. International Journal of Civil Engineering and Technology, 9(9), 2018, pp. 1309-1319.

http://www.iaeme.com/IJCIET/issues.asp?JType=IJCIET\&VType=9\&IType=9

\section{INTRODUCTION}

Today, ICT become an inseparable part of daily live, including education, economic, commerce and even government [1]-[4]. To date, ICT is more become the stimulus for entire elements of sector rather than applied as a facilitator or tool to conduct operations and processes [5]. ICT in government is used to improve the transparence of government itself, 
their responsibility and public services in developed and developing countries [6]. In a government sector, ICT acts to reduce the bureaucracy in term of increasing the efficiency and effectiveness not only in service products, but also in organizational structure and management.

ICT can be realized to increase transparency and accountability in every process of governance and development. The goals are the realization of the reporting system and the performance of government agencies, improving public access to information on the performance of government agencies; implementation of E-Government to support modern bureaucratic management, and increased application of open government in all agencies. The direction of E-Government implementation is to support business processes of governance and development that are simple, efficient and transparent and integrated implemented through strategy. Moreover, the several approaches are including: strengthening EGovernment policies governing institutions, strengthening systems and infrastructure integrated E-Government; improvement/strengthening of electronic procurement systems and the development of electronic catalog systems; and enhancement of ICT-based archival systems [1], [7], [8]. Hence, through ICT, a better government will be occure.

However, an issue regarding the resistance from bureaucray occures in implementing this technology towards government. Furthermore, the resistance is influenced by self-openness, self-effiiciacy, and working culture [9]. Thus, psychology is crucial to be factor that influencing usage of ICT in government. This paper is concerned with tensions to review on existing ICT and Government bureaucracy in psychological perspective.

\section{CONCEPT AND DEFINITION}

\subsection{ICT and E-Government}

ICT stands for three words, namely: Information, Communication, and Technology. The information defined as the output of processing, manipulating and manages a group of data. Then, the process of delivering information (i.e., messages, notions, and ideas,) from one party to another to enable the interplay between them called communication. Technology stated as the application of tools, machines, materials for solving problems. Thus, ICT is the result of human engineering to information process and the process of delivering a message from one party to another resulting in a rapid process, vast distribution, and more massive storage [10]. Meanwhile, E-Government defined as the utilization of ICT to increase the governance processes to fullfil citizen service, providing businesses, employees and agencies, designed by technology, also conducting transaction through the Internet network [11]. The use of ICT in government generating three kinds of terms that usually used by scholars, namely: digital government, electronic governance (E-Governance), and electronic government (E-Government) [12]. Digital government assigned as general term which covering all uses of Information Communication Technology in the public sector [13]. Then, E-Governance is the implies of managing and administering policies and procedures in the private sector by means of ICT. On the other hand, E-Government enables citizens to interact and receive services from the federal, state or local governments, routine and sustainable [14]. Different cases indicate that E-Government have the great potential towards many countries to facilitate their peoples' potency, guiding them to be more productive towards their needs and interests. This technology also facilitates the ability for individuals to participate in the life of their society, government and community [12].

In 2016, United Nations surveyed an overview of E-Government development at the global and regional levels. The study focused on the growing importance and increasing complexity of E-Government, specifically related to its role in promoting effective, inclusive and accountable public services that deliver concrete and people-driven outcomes. Through 
the scoring method called the E-Government Development Index (EGDI), the survey stressed on the Online Service Index, Telecommunication Infrastructure Index, Human Capital Index. The research is designed to give an indicative assessment of the diffusion of E-Government through a performance rating of national governments relative to one another [15]. The summary of the survey illustrates in Table 1.

Table 1 World Top 10 countries for E-Government

\begin{tabular}{rlcccc}
\hline No. & \multicolumn{1}{c}{ Country } & Region & EGDI & EGDI Level & Rank in 2016 \\
\hline 1. & United Kindom & Europe & 0.9193 & Very High & 1 \\
2. & Australia & Oceania & 0.9143 & Very High & 2 \\
3. & Republic of Korea & Asia & 0.8915 & Very High & 3 \\
4. & Singapore & Asia & 0.8828 & Very High & 4 \\
5. & Finland & Europe & 0.8817 & Very High & 5 \\
6. & Sweden & Europe & 0.8704 & Very High & 6 \\
7. & Netherlands & Europe & 0.8659 & Very High & 7 \\
8. & New Zealand & Oceania & 0.8653 & Very High & 8 \\
9. & Denmark & Europe & 0.8510 & Very High & 9 \\
10. & France & Europe & 0.8456 & Very High & 10 \\
\hline
\end{tabular}

\subsection{ICT Strength in Government}

One of the government functions is to provide public services as an effort to meet the societies' needs towards the provision of services. Efforts to improve the state apparatus performance are expected to offer and realize fast, transparent, inexpensive, accessible and accountable services that can be accounted for following the dynamics of the development of increasingly complex community needs [16]. Then, the term of E-Government uprises and drives a new transformation of ICT in the government sector. Tools, media and peripheral are shifting into topics related to core government activities, policy-making, and policy implementation established that E-Government is related to government transformation and reform [17]. According to researcher [18], The use of ICT in government is focused on being a tool to assist the state administration for civil service, by the central public service and the local or state/city government. In developed countries, e-gov is the result of the transformation of bureaucratic interaction mechanisms with communities that are more friendly. Likewise in developing countries, many policymakers believe that clean, authoritative and transparent governance can be realized through E-Government [19]. There are three main characteristics of E-Government, namely: (1) a new mechanism of interaction between the government-community and other interested parties; (2) involves the use of information technology (especially the internet and cellular networks); (3) improve the quality of public services [20].

ICT implementation in government has no particular stage of E-Government due to the variety of technological, social, organizational, economic and political reasons. In other words, applying ICT in government is not a one-step process, but involves several stages or phases of development [21]. Reviewing to several researchers such as [10], [22], [23], the implementation of E-Government has several stages. The stages are including: existence of online sites; interactive services; easiness of transactional acivities; and both vertical (local, state and federal governments) and horizontal (different functions and services) integration.

Howerver, acceptance of ICT things is a two coins condition, it could be accepted or rejected by user. An effort knows the progress of E-Government implementation for internal and external stakeholder become the critical point of organization [24]. Once government 
commit to implement the ICT/e-gov, hence challenges and considerations will be faced, including infrastructure, legislation or policy, human resource, management, partnership, leadership, and strategy [25]. Thus, it is indicates that the emergence of ICT resistance the bureaucracy government organizations.

\subsection{ICT and Government Bureaucracy}

During this time, bureaucratic organizations in the community are well-known to serve negative stereotypes among others. For example, process of managing letters or other documents that are convoluted, unfriendly, unfair, not transparent, complicating and prolonging service. This is due to unpleasant experiences directly are perceived by the community [26]. Bureaucracy in this context means the whole structured government organization which run the nation tasks in every unit of government organization, under department and non-department institutions, in central or region, as in province, regency, subdistrict or villages [27]. The main purpose of the bureaucracy is to achieve nation goals in effectively and efficiently [26]. According to researcher [28], there are several characteristics of bureaucracy, such as: (1) Standardization and formalization; (2) Division and specialization of labor; (3) Authority hierarchy; (4) Professionalization; (5) Written Documentation [29].

The standardization is identified into four aspects, including: standardization of processes, work output, workers' skills and values [30]. On the other hand, formalization is defined as the standardization level of working progress, procedures, instructions and communication are written and executed [31]. In term of bureaucratic organizations, ICT are used to facilitate and control the fundamental organizational functions of coordination. These functions are defined in a set of normative legal rules designed to standardize administrative procedures and delivery of public services. Technologies offered by ICT system such as: database management systems, work flow management systems, automated decision support systems, web services, e-services and cloud shared systems become aid to standardization of bureaucratic processes [1]. In short, ICT helps a bureaucracy system in standardization level of working progress, procedures, instructions and communication among bureaucratic members in an automation of a step in many processes.

Division and specialization of labor defined as details of tasks into simple components that can be carried out on a recurring basis of labor, whereas they have expertise in their fields, even though their work may be only a small part of the overall activities of the organization [31]. All the tasks are carried out by entire process even though these processes are technically different from one another. Whereas by way of specialization of functions, a manager focuses only on one particular function that is different from the functions of other managers. That way, the product is completed only through a combination of work, simultaneously or successfully, from a number of people [29]. By means of ICT, organizations able to utilise employees' capability positioned in a new way in organizing scheme [32]. Emergences of ICT allow to eliminate unnecessary employment and become an aid to accomplish workers job. Also, ICT adoption is able to improving in the number of workers across all categories and simplify the operation [33]. In short, ICT facilitating to arrange labor specilization in their respective fields and shorten the process of any bureaucratic matters.

Then, aspect of authority hierarchy means that an employee is a free person, he is subject to authority only with regard to impersonal obligations of his position. Obedience is intended not to individual officials, but solely to its law-based orders so as to form an impersonal order [28]. The entire elements in a bureaucracy have their own authority to decide policies with responsibility by following applicable laws and regulations. Strategy has been changed in bureaucratic organizations through the use of information technology services, including 
vision, mission, and government policies. The bureaucratic organization that has been providing services directly to users (face to face) has turned into a direct and virtual service with the use of ICT including computerized systems and Internet networks [9]. However, policy and strategies is one of the major challenge to be faced in implementing ICT. The involvement and leadership of chairman from many sector in in government bureaucracy become crucial for the sustainability and successfully of E-Government [34].

ICT reforming the basic structure of bureaucracy into two shapes namely: centralization or decentralization [35]. ICT able to centralize the organization by allowing top-level managers streamlined its operations in managing informations, giving them greater decision strength. Then, ICT also created decentralization by allowing both low and middle level managers to receive the entire problems and situation of their organizations, and providing a corporate works [36]. On the other hand, through the implementation of ICT, informations become easier and free to be accessed by the lower level besides top level. Thus, issues of privacy and security of information become crucial in a government organization [37].

Moreover, professionalization aspect is an ideal skills and knowledge of a bureaucracy members. [38]. Furthermore, researcher [28] stated that a bureaucratic administration should have the knowledge of technology and mastering it. Lastly, a written documentation is needed in a bureaucracy while conducting discussions and preliminary proposals, final decisions, and all kinds of orders and regulations [28]. Recording administrative decisions in writings helps ensure operational continuity. Although officials and administrators come and go alternately, with these written documentation new decisions will continue to be guided by decisions that have been taken in the past. Written documents also facilitate accountability. Higher authorities can use these written records to evaluate the performance of units or agencies and provide guidance that subordinates are responsible for their actions. On the contrary, bureaucrats who are charged with untruth can use written documents to show that they follow the rules and carry out their positions responsibly. Thus the written documentation provides protection for subordinates and superiors [30].

Furthermore, The use of ICT can minimize or also able to eliminate the use of paper in bureaucratic service, with benefits for the environment. By utilizing effective ICT/EGovernment, it can minimize the impact on the environment by reducing waste [39]. ICT presents a centralized government service system where each entity can publish its services to beneficiaries through the use of the Internet and a centralized government database for service accessibility purposes [40]-[42]. Also, implementation of ICT technique able to helps accuracy and security of document [43], [44].

In conclusion, it is hard to implement the ICT or E-Government in bureaucracy. Various challenges will be faced for the integration of E-Government and ICT, namely: strategic, technology, policy, social, financial and organizational [45], [46]. Subsequently, there are a huge number of adaptations and changes regarding cultural, administrative, organizational and legal, that should be suited to the greater effectiveness and efficiency of services [39].

\section{ICT/E-GOVERNMENT: PSYCHOLOGY PRESPECTIVES}

Several studies have been verified that organizational issues is the most important factor in implementation of ICT/E-Goverment [6], [46]-[49]. A radical transformation has taken place along with the use of ICT (E-Government) in the government bureaucracy. Resistance occurs due to changes in habits that have been running all this time. Also, the inability of bureaucrats to use technology is used as an excuse in rejecting the adoption of ICT [9]. Along with that, power or position can also be eliminated by the use of ICT, both authority [34] and economy [50]. Moreover, the organizational issue has been classified into several main problems, namely: culture of organizations, top management support, resistance to applies the electronic 
tools, collaboration, organizational structure and lack of qualified personnel to use ICT [46], [47], [49].

In general, the resistance to utilize ICT in government bureaucratic is caused by negative perception towards the technology usage [9]. The level of usefulness of a technology is determined by the frequency of it used. A good quality of technology shows the perception of the user about the usefulness of the system in an effort to optimize the achievement of the users. A higher perception of the usefulness is concerned to the quality of technology [51]. The differences in perceptions that occur in this government bureaucracy generally relate to differences in understanding and inability of bureaucratic to anticipate the alteration through the use of ICT [9].

According to the Socio-technical systems theory, usage, development and adoption of technology cannot be separated from the human dimension. Social systems are related to people's attributes including skills, values, and attitudes, while technical systems consider tasks, technology, and processes. [52]. In term of user's attitude towards technologies, Technology Acceptance Model (TAM) by researcher [51], stated that perceived usefulness and perceived ease-of-use are become the influenced factor to determining how and when the technology used. The model is widely used to determine the users' psychological factors that influencing the ICT adoption [53]. In line with this, knowledge and skill as parts of a person cognitive, play an important role for users to utilize ICT [54]. Cognitive skills are an important component in a person as a process of thinking power to receive and respond to something. Cognitive skills can bring up one's ideas, ideas, and creativity in learning [55]. Thus, ability or skill and level of knowledge of user is a great factor to strengthen the success of ICT usage [56].

\section{RELATED WORKS ON PSYCHOLOGY PRESPECTIVES OF ICT/E- GOV IMPLEMENTATION}

Succesfull of ICT/E-Gov implementation can not be separated from the organizational. Several studies have been conducted to sought the relationship between psychology prespectives towards ICT/E-Gov implementation. Scholars in investigating ICT and Government are mostly discussed in various objects, countries, also the models. For instance, researcher [57] pointed out that applying E-Government in Kenya as the developing country has a relationship to the concept of public value. Through robust structural equation models, it is showed that public sector pursuit for public value might inform the practice of EGovernance to enhance the skill. Moreover, by using three theories of technology acceptance (UTAUT, TRA, and SCT), a research conducted by researcher [58], investigated factors for the adoption of ICT by city government employees in comparison of Surabaya, Indonesia, and Davao, Philippines. The study stated that performance expectations and attitudes are important factors in influencing the intention to adopt ICT in an organizational structure. Also, as a moderating variable, the employees' age and length of work experience appear to be slightly impression.

A study conducted by researcher [59] revealed that the operational challenges to adopting ICT by employees in Local Government Administration of South Africa are lack of IT skills, and lack of clear understanding of ICT. Next, by using UTAUT model, researcher [60] reported that confidentiality, trust and attitudes toward using technology is primary key determinants to overall satisfaction and the adoption of E-Government services. Furthermore, based on the study reported by researcher [61] which is investigating the underlying factors to use E-Government services in Turkey. The study was conducted by using UTAUT model and evaluated with the Structural Equation Modeling technique with total 529 participants. performance expectancy, social influence, facilitating conditions and trust were found to be 
influencing the behavioral intention of E-Government services usage. According to researcher [62], the adoption of E-Government services is influenced by perceived usefulness and perceived ease of use. By the means of TAM, 40 total respondents are selected to collect both qualitative and quantitative method.

TAM method is used by researcher [6] to examined the survey of E-Government usage in Jordan. Through 413 of total respondents, the research result pointed out that attitude is the most significant determinant factor to adopt and use E-Government service. Then, researcher [63] conducted to study the use of E-Government in India by collecting 300 participants. By using TAM model, perceived the outcome of the research stated that ease of use and perceived usefulness are significant predictors of the intentions to use E-Government services. Moreover, a study conducted by researcher [24] related to user acceptance of E-Government stated that users' personality including optimism and innovative are significantly influenced the technology usage. The research used a survey based on TRAM modelled questionnaire and selected 230 of total samples of customer that had been using E-Government. In the study conducted by researcher [64], TAM, TAM2 and UTAUT was employed to identify the factors influencing the usage of E-Government. The major findings of study reveals that lack of ICT knowledge and skill of users influence the usage of E-Government.

To conclude, using the several studies related to ICT and government, this technology (i.e., E-Government) is convinced to be the high strength to improve government, especially in public services. Meanwhile, there are certain factors to be highlighted in combining ICT and government, namely: performance expectations, attitudes, skills, trust, facilitate, ease of use and perceived usefulness as seen in Table 2.

Table 2 Studies related to ICT/E-Gov and psychology perspective

\begin{tabular}{|c|c|c|c|}
\hline No. & Author (Year) & Theory/Model/Method & Findings \\
\hline 1. & $\begin{array}{l}\text { Venkatesh, Sykes, and } \\
\text { Venkatraman (2014) }\end{array}$ & TAM & $\begin{array}{l}\text { Ease of use and perceived usefulness } \\
\text { are predictors to use E-Government }\end{array}$ \\
\hline 2. & Al-hujran et al. (2015) & TAM & $\begin{array}{l}\text { Attitude is the factor to adopt and use } \\
\text { E-Government }\end{array}$ \\
\hline 3. & $\begin{array}{l}\text { Oyelana and Thakhathi } \\
\text { (2015) }\end{array}$ & Qualitative & Lack of ICT skills influence the usage \\
\hline 4. & Susanto and Aljoza (2015) & TAM & $\begin{array}{l}\text { Perceived usefulness and perceived } \\
\text { ease of use are the factor to adopt E- } \\
\text { Government }\end{array}$ \\
\hline 5 . & $\begin{array}{l}\text { Rodrigues, Sarabdeen, \& } \\
\text { Balasubramanian (2016) }\end{array}$ & UTAUT & $\begin{array}{l}\text { Confidentiality, trust and attitudes are } \\
\text { main factor in ICT adoption }\end{array}$ \\
\hline 6. & Batara (2017) & UTAUT, TRA, SCT & $\begin{array}{l}\text { Performance and attitudes are factors } \\
\text { to utilizing ICT }\end{array}$ \\
\hline & Joseph (2017) & $\begin{array}{l}\text { TAM, TAM } 2 \text {, and } \\
\text { UTAUT }\end{array}$ & $\begin{array}{l}\text { knowledge and skill influence the } \\
\text { usage of E-Government }\end{array}$ \\
\hline 8. & $\begin{array}{l}\text { Kurfali, Arifouglu, } \\
\text { Tokdemir, \& Paçin (2017) }\end{array}$ & UTAUT & $\begin{array}{l}\text { Performance is the factor to adopting } \\
\text { ICT }\end{array}$ \\
\hline 9. & Adiyarta et al. (2018) & TRAM & $\begin{array}{l}\text { Users' personality influence the ICT } \\
\text { usage }\end{array}$ \\
\hline 10. & Okong and Kyobe (2018) & structural equation models & Organizieng practice to enhance skills \\
\hline
\end{tabular}

Based on Table 2, it can be concluded that psychological factors of government bureaucratic are influencing the usage and adoption of ICT/E-Government. Attitudes, ease of use and perceived usefulness from users are the frequently points to come up in recent studies, 
which have a significant contribution towards this technology use. Then, skills and knowledge also mentioned being the prominent factor to achieve the success of ICT/E-Government implementation. Moreover, TAM and UTAUT have become the most used model to gain the information regarding users' intention and psychological factor of technology adoption.

\section{CONCLUSIONS}

ICT/E-Government not only to establish the proper tools to enable policy integration but also have the impact on several areas, namely: social, economic and environmental. Furthermore, this technology is also providing services among various sectors, subsectors, and programmes. ICT/E-Government become an aid of government institutions to combine to overtake common objectives through the entire government approaches. Also, it offers opportunities to re-decision existing decision-making processes and information flows [15]. However, the psychological perspective of government bureaucratic is essential to investigate by the researcher, including their attitude, motivation, self-efficacy, skill, and knowledge. This paper is the framework of the study that will be conducted in North Sumatera, Indonesia. The future study will be conducted to seek the relationship between psychology perspective, ICT skill, and level of ICT knowledge towards the utilization of ICT/E-Government among the government bureaucratic. The next study also deliberates the usage both of TAM and UTAUT as the underpinning model. This article only inspected on a draft of the actual study that will be organized in the future. Also, this paper expected that the following study would discover the similar results towards the previous studies.

\section{REFERENCES}

[1] A. Cordella and N. Tempini, "E - government and organizational change : reappraising the role of ICT and bureaucracy in public service delivery," 2015.

[2] H. Ishida, "The effect of ICT development on economic growth and energy consumption in Japan," Telemat. Informatics, vol. 32, no. 1, pp. 79-88, 2015.

[3] A. H. Lubis, S. Z. S. Idrus, and A. Sarji, "ICT Usage Amongst Lecturers and Its Impact Towards Learning Process Quality," vol. 34, no. 1, pp. 284-299, 2018.

[4] M. D. T. P. Nasution, Y. Rossanty, P. B. Sari, and A. P. U. Siahaan, "ONLINE Shoppers Acceptance: An Exploratory Study," Int. J. Civ. Eng. Tech Nol., vol. 9, no. 6, pp. 793799, 2018.

[5] Y. Mohammad and M. Joghataei, "The Role Of Information And Communications Technology And Bureaucracy In Provision Of Public Services Of Banks Introducti on," Rev. Humanidades e Inovação, vol. 5, no. 2, pp. 129-135, 2018.

[6] O. Al-hujran, M. M. Al-debei, A. Chatfield, and M. Migdadi, "Computers in Human Behavior The imperative of influencing citizen attitude toward e-government adoption and use," Comput. Human Behav., vol. 53, pp. 189-203, 2015.

[7] ICJR, Kajian kebijakan teknologi informasi dan komunikasi. Jakarta, 2015.

[8] J. C. Bertot, P. T. Jaeger, and J. M. Grimes, "Using ICTs to create a culture of transparency: E-government and social media as openness and anti-corruption tools for societies," Gov. Inf. Q., vol. 27, no. 3, pp. 264-271, 2010.

[9] K. Turnip, "Birokrasi Masa Depan dengan Menggunakan Information Technology (Global Network) Perubahan Sikap dalam Mengadopsi Information Technology dan EGovernment," JKAP (Jurnal Kebijak. dan Adm. Publik), vol. 7, no. 1, pp. 63-78, 2015.

[10] World Bank Staff, Information and Communication Technologies: A World Bank Group Strategy. World Bank Publications, 2002.

[11] T. F. Gordon, "E-Government-Introduction,” ERCIM News, vol. 48, pp. 12-13, 2002.

http://www.iaeme.com/IJCIET/index.asp 1316 editor@iaeme.com 
[12] J. P. Gant, "Electronic government for developing countries," Int. Telecommun. Union (ITU), Geneva, 2008.

[13] G. D. Garson, Public information technology and e-governance: Managing the virtual state. Jones \& Bartlett Learning, 2006.

[14] S. C. J. Palvia and S. S. Sharma, "E-government and e-governance: definitions/domain framework and status around the world," in International Conference on E-governance, 2007, pp. 1-12.

[15] U. N. D. E. S. Affairs, United Nations E-Government Survey 2016: E-Government in Support of Sustainable Development. 2017.

[16] R. Radiansyah, S. Surachman, and S. Sunaryo, "Faktor-Faktor yang Mempengaruhi Kesuksesan Penerimaan Teknologi Sistem Informasi Manajemen Pemerintah dan Dampaknya terhadap Kinerja Karyawan (Studi pada Direktorat Jenderal Perbendaharaan)," J. Apl. Manaj., vol. 14, no. 4, pp. 683-696, 2016.

[17] V. Homburg, "ICT, E-Government and E-Governance: Bits \& Bytes for Public Administration," in The Palgrave Handbook of Public Administration and Management in Europe, Springer, 2018, pp. 347-361.

[18] F. Bannister and R. Connolly, "ICT, public values and transformative government: A framework and programme for research," Gov. Inf. Q., vol. 31, no. 1, pp. 119-128, 2014.

[19] R. E. Indrajit, Electronic government: strategi pembangunan dan pengembangan sistem pelayanan publik berbasis teknologi digital. Andi, 2002.

[20] E. S. Holle, "Pelayanan Publik Melalui Electronic Government; Upaya Meminimalisir Praktek Maladministrasi Dalam Meningkatkan Public Service," J. Sasi, vol. 17, no. 3, 2011.

[21] M. Alshehri and S. Drew, "Implementation of e-government: advantages and challenges," in International Association for Scientific Knowledge (IASK), 2010.

[22] Gartner Research, "Traditional ROI measures will fail in government," sourced from, 2003.

[23] K. Layne and J. Lee, "Developing fully functional E-government: A four stage model," Gov. Inf. Q., vol. 18, no. 2, pp. 122-136, 2001.

[24] K. Adiyarta, D. Napitupulu, H. Nurdianto, R. Rahim, and A. Ahmar, "User acceptance of E-Government Services Based on TRAM model," in IOP Conference Series: Materials Science and Engineering, 2018, vol. 352, no. 1, p. 12057.

[25] V. Ndou, "E--Government for developing countries: opportunities and challenges," Electron. J. Inf. Syst. Dev. Ctries., vol. 18, no. 1, pp. 1-24, 2004.

[26] R. Martini, "Buku Ajar Birokrasi dan Politik." LPPMP UNIVERSITAS DIPONEGORO, 2012.

[27] P. J. Sellers, "Strategy and background in congressional campaigns," Am. Polit. Sci. Rev., vol. 92, no. 1, pp. 159-171, 1998.

[28] M. Weber, From Max Weber: essays in sociology. Routledge, 2013.

[29] A. Kadir, "Prinsip-prinsip Dasar Rasionalisasi Birokrasi Max Weber Pada Organisasi Perangkat Daerah Kota Kendari Provinsi Sulawesi Tenggara," JAKPP J. Anal. Kebijak. Pelayanan Publik, vol. 1, no. 1, pp. 40-54, 2015.

[30] J. Tompkins, Organization theory and public management. Thomson Wadsworth Belmont, CA, 2005.

[31] S. P. Robbins and N. Barnwell, Organisation theory: Concepts and cases. Pearson Education Australia Frenchs Forest, NSW, 2006. 
[32] M. Petković and J. Lukić, "New organizational forms supported by the information and communication technology: the case of Serbian ICT industry," Facta Univ. Ser. Econ. Organ., pp. 101-115, 2014.

[33] I. Brambilla and D. Tortarolo, Investment in ICT, productivity, and labor demand: the case of Argentina. The World Bank, 2018.

[34] R. Cullen and G. Hassall, "e-Government in the Pacific Island states: ICT policy and implementation in small island developing states: Vanuatu Country Report," 2016.

[35] O. Taylan, "The strategic role of an organization in developing a modern information system," Deniz Bilim. ve Mühendisli \u\{g\}\}i Derg., vol. 6, no. 3, 2010.

[36] T. Dewett and G. R. Jones, "The role of information technology in the organization: a review, model, and assessment," J. Manage., vol. 27, no. 3, pp. 313-346, 2001.

[37] B. Gupta, S. Dasgupta, and A. Gupta, "Adoption of ICT in a government organization in a developing country: An empirical study," J. Strateg. Inf. Syst., vol. 17, no. 2, pp. 140-154, 2008.

[38] S. M. Yates, "Professional Competencies: Perspectives and Challenges for the Tertiary Sector," in International Perspectives on Competence in the Workplace, Springer, 2009, pp. 87-99.

[39] S.-D. Orantes-Jimenez, A. Zavala-Galindo, and G. Vazquez-Alvarez, "Paperless Office: a new proposal for organizations," Syst. Cybern. Informatics, vol. 13, no. 3, pp. 47-55, 2015.

[40] A. O. Ogunde and C. Odukwe, "A Prototype System for Mining Frequent Citizens' Demand Patterns from E-Government Databases," Notes for Authors, p. 1, 2017.

[41] S. M. Qader, B. A. Hassan, and M. H. R. Saeed, "A New ICT Framework to Adopt ICT Projects: KRG Organisations as Case Study," Kurdistan J. Appl. Res., vol. 2, no. 3, pp. $18-24,2017$.

[42] N. V. Hung, P. van Hung, and B. T. Anh, "Database Design For E-Governance Applications: A Framework For The Management Information Systems Of The Vietnam Commitee For Ethnic Minority Affairs (CEMA)," Int. J. Civ. Serv. Reform Pract., vol. 3, no. $1,2018$.

[43] A. P. U. Siahaan et al., "Combination of Levenshtein Distance and Rabin-Karp to Improve the Accuracy of Document Equivalence Level," Int. J. Eng. Technol., vol. 7, no. 2.27, pp. 17-21, 2018.

[44] A. Al-Haj and H. Barouqa, "Copyright protection of e-government document images using digital watermarking," in Information Management (ICIM), 2017 3rd International Conference on, 2017, pp. 441-446.

[45] T. A. Pardo, T. Nam, and G. B. Burke, "E-government interoperability: Interaction of policy, management, and technology dimensions," Soc. Sci. Comput. Rev., vol. 30, no. 1, pp. 7-23, 2012.

[46] L. Waller and A. Genius, "Barriers to transforming government in Jamaica: Challenges to implementing initiatives to enhance the efficiency, effectiveness and service delivery of government through ICTs (e-Government)," Transform. Gov. People, Process Policy, vol. 9, no. 4, pp. 480-497, 2015.

[47] M. Al-Sebie, "Organizational challenges facing integrating e-government systems: an empirical study," Eur. Sci. Journal, ESJ, vol. 10, no. 10, 2014.

[48] L. Anthopoulos, C. G. Reddick, I. Giannakidou, and N. Mavridis, "Why e-government projects fail? An analysis of the Healthcare. gov website," Gov. Inf. Q., vol. 33, no. 1, pp. 161-173, 2016.

[49] N. Nurdin, R. Stockdale, and H. Scheepers, "Influence of Organizational Factors in the Sustainability of E-Government: A Case Study of Local E-Government in Indonesia," in 
Trends, Prospects, and Challenges in Asian E-Governance, IGI Global, 2016, pp. 281323.

[50] K. Lee, S. Choi, J. Kim, M. Jung, and others, "A Study on the Factors Affecting Decrease in the Government Corruption and Mediating Effects of the Development of ICT and EGovernment-A Cross-Country Analysis," J. Open Innov. Technol. Mark. Complex., vol. 4, no. 3, p. 41, 2018.

[51] F. D. Davis, "Perceived usefulness, perceived ease of use, and user acceptance of information technology," MIS Q., pp. 319-340, 1989.

[52] R. P. Bostrom and J. S. Heinen, "MIS problems and failures: a socio-technical perspective, part II: the application of socio-technical theory," MIS Q., pp. 11-28, 1977.

[53] N. Marangunić and A. Granić, "Technology acceptance model: a literature review from 1986 to 2013," Univers. Access Inf. Soc., vol. 14, no. 1, pp. 81-95, 2015.

[54] B. A. Pusso and A. Ahmad, "Ict Skills Among Iban Students In Sarawak," in International Conference on Education and Regional Development 2016, 2016, pp. 8995.

[55] A. Atika and Kamaruzzaman, "Hubungan Keterampilan Kognitif Dengan Kemampuan Mewujudkan Gagasan Pada Mahasiswa Semester Pendek Program Studi Bk Stkip-Pgri Pontianak Tahun 2011/2012," Sos. Horiz. J. Pendidik. Sos., vol. 1, no. 1, pp. 13-22, 2016.

[56] N. Akbar, V. Ratnawati, and V. Novita, "Pengaruh pengetahuan teknologi informasi, pemanfaatan teknologi informasi, dan faktor kesesuaian tugas-teknologi terhadap kinerja akuntan internal," J. Ekon., vol. 18, no. 02, 2013.

[57] K. Okong and M. Kyobe, "Empirical Examination of e-Government in Developing Countries and its Value in Kenya 's Public Service," vol. 21, no. 1, pp. 35-45, 2018.

[58] E. B. Batara, "Adopting Organizational Structuring for ICT-enabled Government Transformation: Perspectives of City Government Employees in Indonesia and the Philippines," governance, vol. 3, no. 4, p. 5, 2017.

[59] A. A. Oyelana and D. R. Thakhathi, "Assessing the Role of Information and Communication Technology (ICT) in Enhancing Employees' Performance in a Selected Local Government Administration (LGA) in South Africa," J. Commun., vol. 6, no. 1, pp. 229-235, 2015.

[60] G. Rodrigues, J. Sarabdeen, and S. Balasubramanian, "Factors that influence consumer adoption of e-government services in the UAE: A UTAUT model perspective," J. Internet Commer., vol. 15, no. 1, pp. 18-39, 2016.

[61] M. Kurfali, A. Arifouglu, G. Tokdemir, and Y. Paçin, "Adoption of e-government services in Turkey," Comput. Human Behav., vol. 66, pp. 168-178, 2017.

[62] D. Susanto and M. Aljoza, "Individual acceptance of e-Government services in a developing country: Dimensions of perceived usefulness and perceived ease of use and the importance of trust and social influence," Procedia Comput. Sci., vol. 72, pp. 622-629, 2015.

[63] V. Venkatesh, T. A. Sykes, and S. Venkatraman, "Understanding e-Government portal use in rural India: role of demographic and personality characteristics," Inf. Syst. J., vol. 24, no. 3, pp. 249-269, 2014.

[64] B. K. Joseph, "Multi-Dimensional Nature of e-Government: Towards Adaptive eGovernment Models," in International Symposium on Computer Science and Artificial Intelligence (ISCSAI), 2017, vol. 1, no. 3, pp. 1-5. 